\title{
ASSESSING URBAN HEAT ISLAND IMPACT ON LONG-TERM TRENDS OF AIR TEMPERATURES IN LJUBLJANA
}

Darko Ogrin, PhD., Marko Krevs, PhD.

Department of Geography, Faculty of Arts, University of Ljubljana

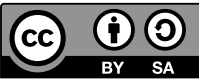

Aškerčeva 2, SI-I000 Ljubljana

E-mails: darko.ogrin@ff.uni-lj.si, marko.krevs@ff.uni-lj.si

Original scientific article

COBISS 1.01

DOI: $10.4312 /$ dela.43.3.41-59

\begin{abstract}
The paper presents an assessment of urban heat island (UHI) impact on air temperature trends in Ljubljana. The assessments are based on the comparison between the long-term air temperature trends in Ljubljana and Zagreb. Meteorological station Zagreb-Grič operated on the hill in the city centre since its establishment in 1862, while the Ljubljana station changed its location several times. The analysed UHI effect on the measurements of air temperature in Ljubljana gradually increased, especially after 1950.
\end{abstract}

Key words: urban heat island, climate change, instrumental period, temperature trends, Ljubljana, Zagreb

\section{OCENA VPLIVA MESTNEGA TOPLOTNEGA OTOKA NA DOLGOROČNE TRENDE SEGREVANJA OZRAČJAV LJUBLJANI}

\section{Izvleček}

$\mathrm{V}$ prispevku je ocenjen vpliv mestnega toplotnega otoka (MTO) na trende segrevanja ozračja v Ljubljani. Ocene temeljijo na primerjavi dolgoročnih trendov temperature zraka v Ljubljani in Zagrebu. Meteorološka postaja Zagreb-Grič deluje od ustanovitve leta 1862 ves čas na griču v središču mesta, medtem ko se je ljubljanska postaja večkrat selila. Analizirani učinek MTO na trende temperature zraka v Ljubljani se je postopoma povečeval, zlasti po letu 1950 .

Ključne besede: mestni toplotni otok, spreminjanje podnebja, instrumentalno obdobje, temperaturni trendi, Zagreb, Ljubljana 


\section{INTRODUCTION}

In the last 25 years the science dedicates a lot of attention to so-called historical climatology, which is engaged in researching past climate. Among the main reasons for the increased attention are certainly contemporary global and regional climate changes and fluctuations, which are manifested in several ways. In Slovenia for example, with the emergence of green and mild winters followed by very hot and dry summers at the end of the 1980s, and recently with the universal rise in the air temperature and increasing frequency of extreme weather events. In order to evaluate these processes and events correctly - to establish whether they already anticipate a changed climate or whether they are just the result of usual weather and climate variability - and prepare scenarios of the future climate and its (possible) results in natural and social environments, it is necessary to be accurately acquainted with the history of climate, both in pre-instrumental and instrumental periods for which measurement and observation data of meteorological stations are available.

To study the climate variability in Slovenia during the instrumental period of over a hundred years, five meteorological stations can mainly be taken into account. Two of them operate on the Slovenian territory, i.e. Ljubljana and Maribor, and three in the vicinity, i.e. Trieste, Zagreb and Villacher Alps. These stations began with measurements and observations in the mid-19th or the second half of the 19th century and have collected continuous series of data of sufficient quality. Temperature and precipitation data have been collected for Trieste since 1841, for Ljubljana and Villacher Alps since 1851, for Zagreb since 1862, and for Maribor since 1876. Trieste nicely exemplifies climate changes in Slovenian areas with moderate mediterranean climate, Ljubljana in the areas with subalpine variety of moderate continental climate of central Slovenia, Maribor and Zagreb represent the moderate continental climate of eastern Slovenia (subpannonian climate), and Villacher Alps the mountain climate (Ogrin D., 1996; Ogrin D., Plut, 2009).

The basic problem of analysing the series of climatic data over many years and establishing the changeability and climate trends arises from lack of homogeneity of data series. To obtain reliable results, the meteorological stations should have operated at the same places all the time, their surroundings should not have significantly changed nor the technology and methodology of measurements or observations. Wherever these circumstances of measurements have changed, detailed metadata about the history of observations are needed to correct and homogenise the data series. The problem of data series homogeneity is particularly acute with urban meteorological stations. These stations often migrate from the centre to the periphery, cities grow during the instrumental measurements period, the surroundings of these stations is urbanised and all that influence the measurements of air temperature. Although this impact cannot be entirely eliminated in the process of data homogenisation, the long-term trends of warming in the cities are much higher than in non-urban stations. This fact contributes to the problems of the identification of general trends in warming and regional responses to global warming. 
The mentioned problem of large impact of urban climate on measurements of air temperature, and consequently the warming trend, is encountered also in Ljubljana. Beside the several relocations of the meteorological station in the first century of the measurements, its migration after the Second World War from the city centre to Bežigrad at the margin of the city, urbanised in the next decades, including densely building-up the surrounding areas of the station, is especially important for evaluating the long-term warming trends (Dolinar et al., 2010). Because of this, the warming trends for Ljubljana, especially in the last 30 years, even when using homogenised data, greatly exceed the world averages (Dolinar, Vertačnik, 2010).

It is not possible to determine precisely how much of the warming trend is due to the urban heat island. In the case of Ljubljana, we have tried to assess the influence of the urban climate on the warming trend in mean annual and seasonal air temperatures by comparing trends with Zagreb. The meteorological station Zagreb-Grič has not moved in more than 150-years history. It is located on a hill Grič, which has not experienced major urban and other changes from the second half of the 19th century. We therefore believe that the impact of the city's enlargement on temperature trends in Zagreb is minimal, and that the increased differences in trends between Ljubljana and Zagreb after 1950 can be attributed to the increased impact of urban heat island of Ljubljana on the measurements of the air temperature.

Temperature and precipitation series for Ljubljana and Zagreb have already been studied individually in the scholarly literature at different times; Ljubljana: Manohin (1952; 1965), Gams and Krevs (1990), Kajfež-Bogataj (1990; 1992), D. Ogrin (2003; 2015), Vysoudil and Jurek (2005), Bertalanič et al. (2010), Dolinar et al. (2010); Zagreb: Goldberg (1953), Šegota (1970; 1981), Juras (1985), Penzar, Juras and Marki (1992), Penzar et al. (1992a), Radić, Pasarić and Šinik (2004), Zaninović (2006), etc. Hence it follows that the problem of climate changing and establishing the trends of changes has not been topical only in the last decades, when the opinion prevails that a human is the main culprit of the current changing, but these questions became a subject of research soon after the sufficiently long series of climate data had been available.

The urban heat island phenomenon has been in focus of several theoretical debates (e.g. in Oke, 1999; Souch, Grimmond, 2006; Gartland, 2008) as well as in case studies carried out in cities in Slovenia (Žiberna, 1991; Jernej, 2000; Konovšek, 2006), Central Europe (Lazar, Buchroithner, Kaufmann, 1995; Bottyán et al., 2005; Bokwa, 2011; Vysoudil et al., 2012) and elsewhere (Wanner, 1991; Montávez, Rodríguez, Jiménez, 2000; Kim, Baik, 2002). However, relevant examples of the analyses of the impacts of urban heat island on long-term temperature trends have not been found in the literature.

\section{DATA SERIES AND METHODS}

To determine the long-term temperature trends in Ljubljana and Zagreb, and the impact of the Ljubljana urban climate on warming trends, we analysed homogenised and non-homogenised data. The source of homogenised data was the website of the project HISTALP, where the long-term series of climate measurements for the territory of the 
Alps are collected (Auer et al., 2007). The non-homogenised database has been composed of published series of data over many years for Ljubljana (Krevs, 1986; Klimatografija Slovenije, 1995) and for Zagreb (Penzar, Juras, Marki, 1992). The base has been upgraded for Ljubljana for the last 20 years with the data from the archives of the National Meteorological Service at the Slovenian Environment Agency (Agencija RS za okolje/ ARSO), and the 1990-2010 data for Zagreb from the archives of the Hydrometeorological Institute of Croatia (Državni hidrometeorološki zavod Republike Hrvatske). The basis of our calculations have been the average annual and seasonal temperatures, for Ljubljana for the period 1851-2010 and for Zagreb-Grič for the period 1862-2010.

Figure 1: Locations of meteorological observations in Ljubljana and Zagreb Slika 1: Lokacije meteoroloških opazovalnih prostorov v Ljubljani in Zagrebu

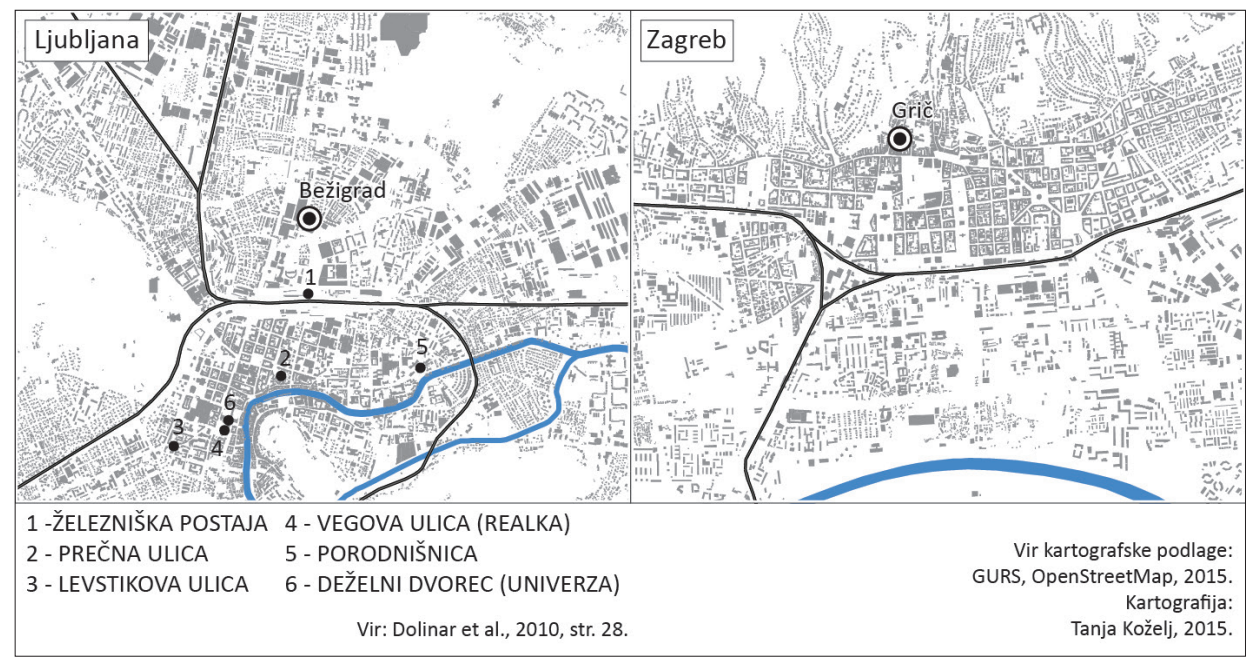

The meteorological station of Ljubljana has changed its location and instrumentation several times in its 150-year history, while the Zagreb station has only changed its micro-location and instrumentation. In view of the homogeneity of data series, the Zagreb station is in better position since it has operated throughout at Grič (157 m a.s.1.). It was only in the initial period of measurements that, due to extending the Royal Secondary Modern School, the Stevenson screen was moved from the northern to the southern wing of the building; however, it was all the time located on the northern side, on a window on the first-floor. The fact that the station was not moved may mainly be credited to the world-famous geophysicist Andrija Mohorovičić, who was, on the basis of his own observations, familiar with the characteristics of the city's climate and the impact of moving the station on the homogeneity of the measured data (Mohorovičić, 1897; Herak, Penzar, Herak, 2011). The Zagreb-Grič station has a complete series of temperature (and precipitation) data, since its operation did not stop even during the First and the Second World Wars, despite certain troubles (Katušin, 2011). 
The station in Ljubljana was moved longer distances within the city. Despite the corrections made for Ljubljana, its data are less homogenous, due to a more versatile history and somewhat poorer knowledge of measurement circumstances in individual periods and a greater number of interpolated values, and above all, due to the moving of the station after the Second World War to the northern fringe of the city (Bežigrad, $299 \mathrm{~m}$ a.s.1.). According to Trontelj (2000), after the moving of the station in 1947, measurements were done on a 'large meadow' which was gradually built-up in the following decades and thus the measurement circumstances were significantly changed. Therefore, the impact of urban climate is present in temperature series for Ljubljana, also in the homogenised data series, which have been our basis for the assessment of the urban heat island on the warming trends.

Table 1: A short overview of the history of meteorological observations in Ljubljana and Zagreb

Preglednica 1: Kratek pregled zgodovine meteoroloških opazovanj v Ljubljani in Zagrebu

\begin{tabular}{|c|c|}
\hline Ljubljana* & Zagreb-Grič ${ }^{* *}$ \\
\hline $\begin{array}{l}\text { 1850-1852: Telegraph office of the railway station, } \\
\text { 1st floor - east, at the fringe of the city at that time, } \\
298 \mathrm{~m} \text { a.s.l. }\end{array}$ & $\begin{array}{l}\text { 1861-1864: The Great Secondary School, 1st floor- } \\
\text { northern wing of the building }\end{array}$ \\
\hline $\begin{array}{l}\text { 1853-1895: Prečna ulica street, } 295 \text { m, } 298 \text { m, } 290 \text { m } \\
\text { a.s.1.; data for } 1863 \text { and } 1864 \text { are missing; city centre }\end{array}$ & $\begin{array}{l}\text { 1864: Stevenson screen relocated to the } 1 \text { st floor of } \\
\text { the southern wing }\end{array}$ \\
\hline $\begin{array}{l}\text { 1895-1919: precipitation measurements; Levstikova } \\
\text { ulica street, } 297 \text { m a.s.l. }\end{array}$ & $\begin{array}{l}\text { 1861-1891: meteorological measurements and } \\
\text { observations managed by I. Stožir }\end{array}$ \\
\hline $\begin{array}{l}\text { 1895-1924: Secondary school in Vegova ulica } \\
\text { street, station relocations within the building } 306 \\
\text { m, } 304 \text { m, } 297 \mathrm{~m} \text { a.s.l.; city centre } \\
\text { 1921-22: parallel air temperature measurements at } \\
\text { Šiška and in Šlajmerjeva ulica street }\end{array}$ & $\begin{array}{l}\text { 1892: observations taken over by A. Mohorovičić, } \\
\text { gradual replacement of instruments }\end{array}$ \\
\hline $\begin{array}{l}\text { 1921-1948: the University building, Institute of } \\
\text { Geography, station relocations within the building, } \\
309 \text { m, } 305 \text { m, } 295 \text { m a.s.l; city centre }\end{array}$ & $\begin{array}{l}\text { 1896: Secondary school moves to a new location, } \\
\text { meteorological observatory remains on its original } \\
\text { location }\end{array}$ \\
\hline $\begin{array}{l}1948-\text { : Bežigrad, Celjska (Vojkova) ulica street, } \\
299 \text { m a.s.l.; fringe of the city, later densely built-up }\end{array}$ & $\begin{array}{l}\text { Uninterrupted daily recording of climate elements } \\
\text { since } 1861 ; 157 \mathrm{~m} \text { a.s.l. }\end{array}$ \\
\hline
\end{tabular}

Sources/Viri: * Gavazzi, 1925; Povše, 1984; Trontelj, 2000; ** Katušin, 2011; Herak, Penzar, Herak, 2011 
Figure 2: The seat of the University of Ljubljana (former Provincial Mansion), where the Geographical Institute carried out measurements of air temperatures between 1921 and 1948 (postcard from 1913; collection D. Ogrin)

Slika 2: Sedež Univerze v Ljubljani (nekdanji deželni dvorec), kjer so na Geografskem inštitutu potekale meritve temperature zraka med leti 1921 in 1948 (razglednica iz leta 1913; zbirka D. Ogrin)

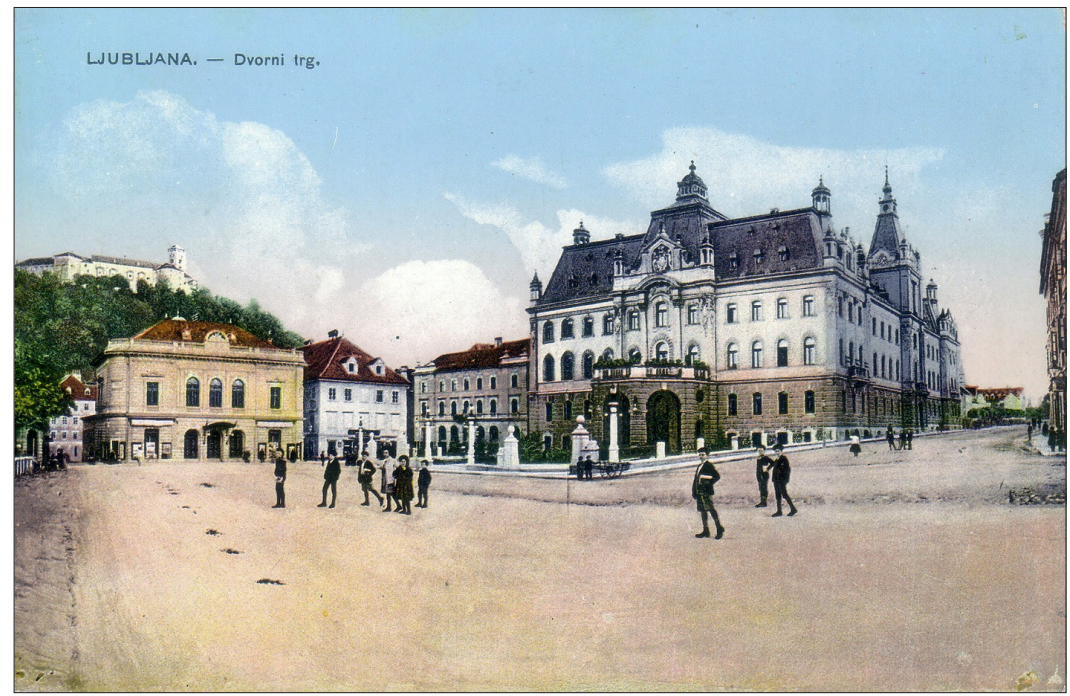

To study the temperature trends, we used linear regression analysis and Mann-Kendall trend test. With the first method, we assessed rates of temperature change in the studied time series. Linear regression analysis is one of the parametric methods and among the conditions for its use is a normal frequency distribution of the data. The latter was verified using Kolmogorov-Smirnov test with Lilliefors correction and Shapiro-Wilks test. Analyses have shown pronounced deviations from normal frequency distribution for several studied time series. Also the trends observed by linear regression analysis, and tests of their statistical significance, show considerable differences between them. Methodological issues and the results of these analyses deserve a more detailed consideration and will be dealt within a separate article. In this paper some selected calculations were used mainly to illustrate the effects of urban heat island in temperature trends.

Since the non-normality of the frequency distribution of the data and the absence of statistically significant linear trends are common phenomena in the study of climate, the use of nonparametric methods for studying trends is a common practice. These methods are robust, insensitive to the frequency distribution of the data (Mann, 1945; Kendall, 1975; Hirsch, Slack, Smith, 1982) and give much more 'loose' results compared to parametric methods. Among the most widespread is the Mann-Kendall trend test with Lilliefors correction. It is based on a rank correlation (Kendall's tau) and is intended to test only the monotony of the trend, i.e. whether data are monotonously 
rising or falling, or confirm the null hypothesis that there is no trend in the time series (or, otherwise, these data are randomly distributed in the time series). The 'loose' results are evident also in our research, as the method shows the existence of statistically significant monotonous trends also in some cases, where the linear regression analysis shows statistically insignificant trends.

Descriptive statistics, linear trends and 20-years moving averages in our study have been calculated using Excel for Windows (Microsoft; 2013) and SPSS (IBM; 2013), and the Mann-Kendall trend test using XLSTAT (Addinsoft; 1995-2014).

\section{RESULTS AND DISCUSSION}

\section{I 100-years trends in mean annual and seasonal air temperatures in Ljubljana and Zagreb}

The results of the analyses of the homogenised data show the same variability in the mean annual air temperatures in Ljubljana and Zagreb, and minor differences in variability of seasonal temperatures. The most variable temperatures in both cities are found in the winter, and the least variable in the summer. Also, the most pronounced trends of warming since the mid-19th century are found in the winter. In Ljubljana, the trends of warming are more pronounced, both in homogenised and non-homogenised data (Tables 2 and 3). Although, without taking the impact of the urban climate into account, we would expect more pronounced warming trends in Zagreb, due to more continental character of its temperature regime. Seasonal temperatures in Ljubljana, without exception, have been increasing since the mid-19th century to the present day. The warming trend is the most pronounced in winter, which is demonstrated in the increase of the winter temperatures in Ljubljana by more than $2{ }^{\circ} \mathrm{C}$ from the mid-19th century to the present day. Until the early 20th century, the winter temperatures were below-average, in the middle of the first half of that century several exceptionally warm winters have been encountered, and in the next few decades winter temperatures have variated around 150-year average. From the 1980s on, there is a pronounced upward trend in winter temperatures. Winter is followed by spring, and similar trend is evident in mean annual temperatures. Summer temperatures have increased more intensely in the last 25 years, when the mean summer temperature has been by $1.5^{\circ} \mathrm{C}$ higher than the 160 -year average.

The coldest year in the studied period was 1871, and the warmest was 2000. Very warm years have mainly occurred in a row since 2000. The coldest winters were in the first 100 years of measurements. Very warm winters are most typical for the last two decades (the warmest winter 2006/07) and for the beginning of the 20th century. The latter period was followed by a fast decrease in winter temperatures. The warmest summer was in 2003. Besides hot summers of the past two decades, there were some already at the beginning of measurements and in the mid-20th century. In contrast, cool summers in Ljubljana occurred at the beginning of measurements and in the first half of the 20 th century. 
Figure 3: Changes in mean air temperatures in Ljubljana (1851-2010)

Slika 3: Spreminjanje povprečnih temperatur zraka v Ljubljani (1851-2010)

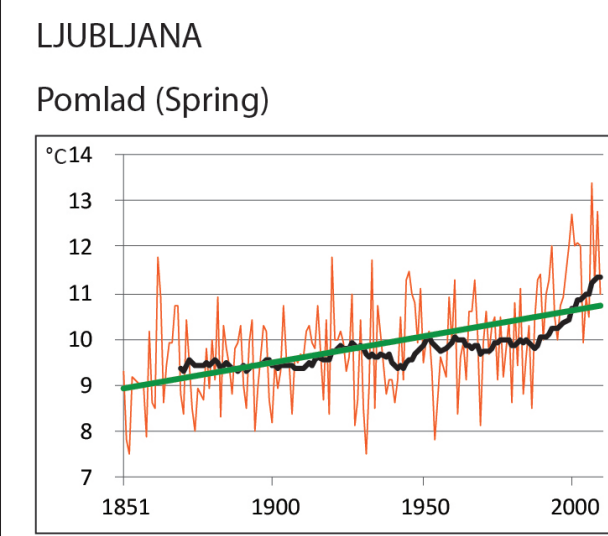

Jesen (Autumn)

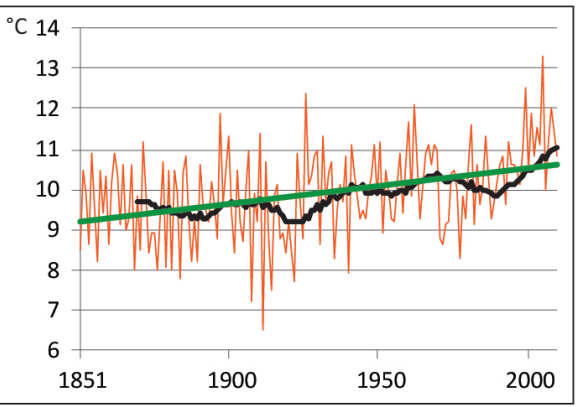

Poletje (Summer)

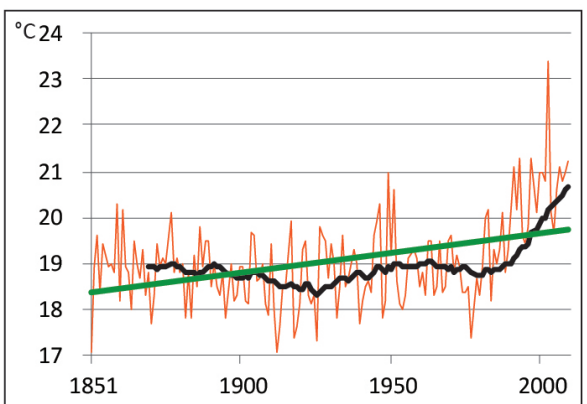

\section{Zima (Winter)}

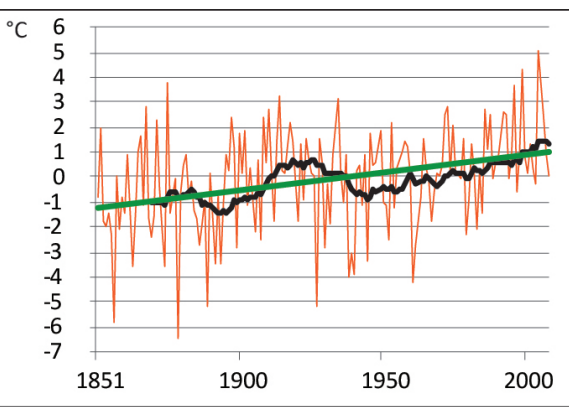

\section{Leto (Year)}

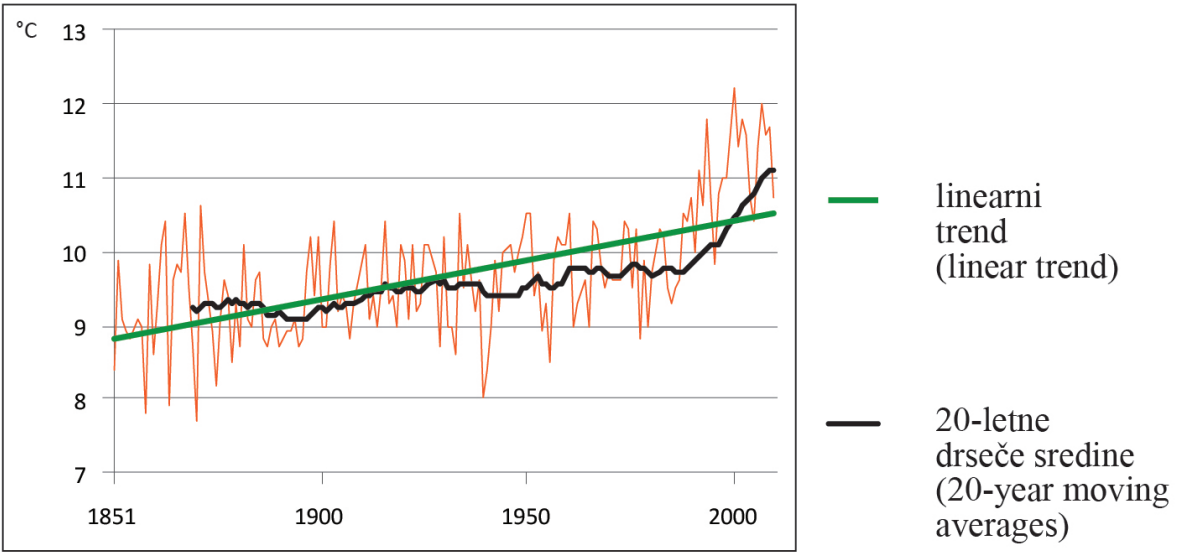


Figure 4: Changes in mean air temperatures in Zagreb (1862-2010)

Slika 4: Spreminjanje povprečnih temperatur zraka v Zagrebu (1862-2010)

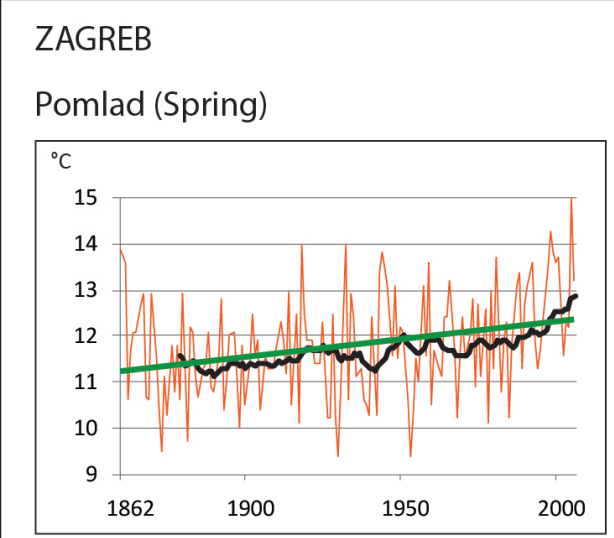

Jesen (Autumn)

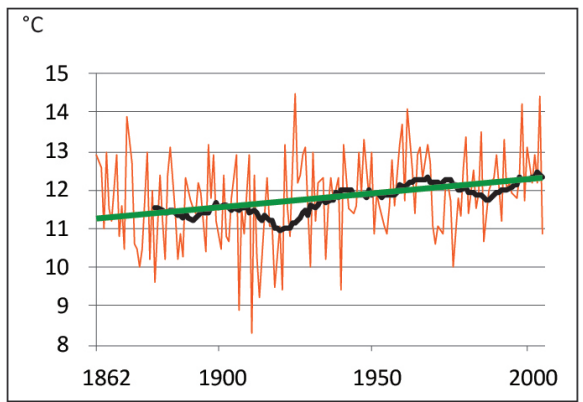

Poletje (Summer)

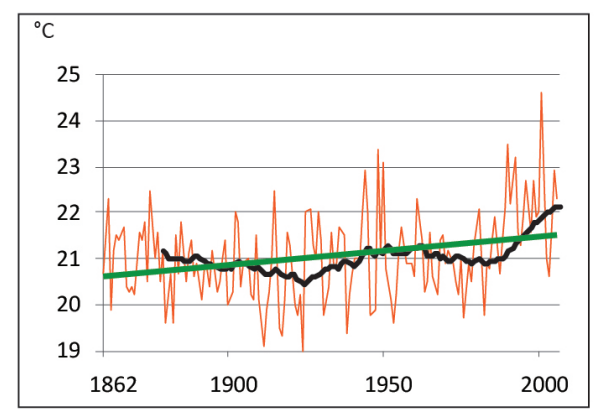

\section{Zima (Winter)}

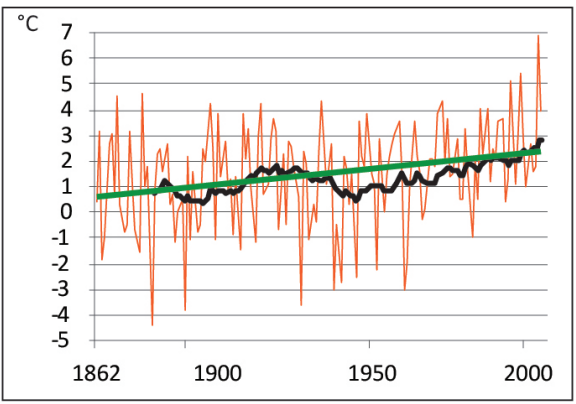

Leto (Year)

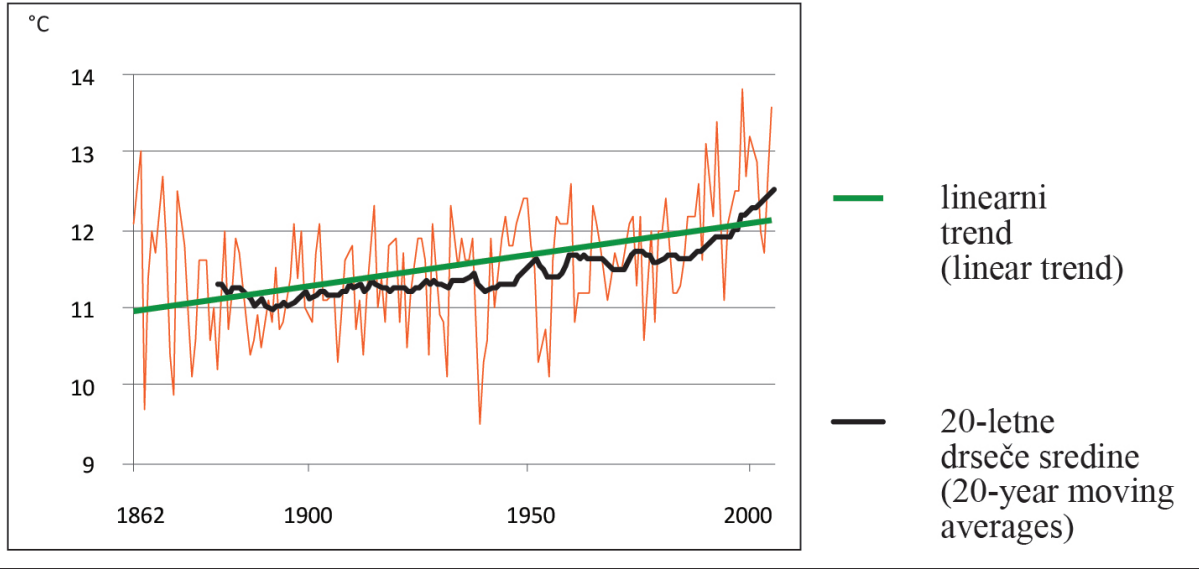


Table 2: Variability of the air temperature in Ljubljana in the period $1851-2010$ (in ${ }^{\circ} \mathrm{C}$ ) Preglednica 2: Spremenljivost temperature zraka v Ljubljani v obdobju 1851-2010 ( $\left.{ }^{\circ} \mathrm{C}\right)$

\begin{tabular}{|l|c|c|l|l|l|l|l|}
\cline { 2 - 8 } \multicolumn{1}{c|}{} & Avrg. & $\begin{array}{l}\text { Stand. } \\
\text { deviation }\end{array}$ & $\begin{array}{l}\text { Coolest sea- } \\
\text { son (year) }\end{array}$ & $\begin{array}{l}\text { Warmest } \\
\text { season (year) }\end{array}$ & $\begin{array}{l}\text { Trend* }\left({ }^{\circ} \mathrm{C} /\right. \\
100 \text { years) }\end{array}$ & $\begin{array}{l}\text { The warmest } \\
\text { seasons (years) }\end{array}$ & $\begin{array}{l}\text { The coolest } \\
\text { seasons (years) }\end{array}$ \\
\hline Spring & 9.9 & 1.1 & $7.5(1932)$ & $13.4(2007)$ & $\begin{array}{l}+1.1 \\
(+1.3)^{* *}\end{array}$ & $\begin{array}{l}2007,2009,2000, \\
2002\end{array}$ & $\begin{array}{l}1932,1853,1955, \\
1958\end{array}$ \\
\hline Summer & 19.0 & 1.0 & $\begin{array}{l}17.1(1851, \\
1913)\end{array}$ & $23.4(2003)$ & $\begin{array}{l}+0.9 \\
(+1.0)^{* *}\end{array}$ & $\begin{array}{l}2003,1994,1998, \\
2010\end{array}$ & $\begin{array}{l}1851,1913,1926, \\
1918,1978\end{array}$ \\
\hline Autumn & 9.9 & 1.1 & $6.5(1912)$ & $13.3(2006)$ & $\begin{array}{l}+0.9 \\
(+0.9)^{* *}\end{array}$ & $\begin{array}{l}2006,2000, \\
1926,1963\end{array}$ & $\begin{array}{l}1912,1908,1915, \\
1922\end{array}$ \\
\hline Winter & -0.1 & 1.8 & $\begin{array}{l}-6.5 \\
(1879 / 80)\end{array}$ & $5.1(2006 / 07)$ & $\begin{array}{l}+1.4 \\
(+1.7)^{* *}\end{array}$ & $\begin{array}{l}2006 / 07,2000 / 01, \\
1876 / 77,1997 / 98\end{array}$ & $\begin{array}{l}1879 / 80,1857 / 58, \\
1890 / 91,1928 / 29\end{array}$ \\
\hline Year & 9.7 & 0.8 & $7.7(1871)$ & $12.2(2000)$ & $\begin{array}{l}+1.1 \\
(+1.2)^{* *}\end{array}$ & $\begin{array}{l}2000,2007,1994, \\
2002\end{array}$ & $\begin{array}{l}1871,1858,1864, \\
1940\end{array}$ \\
\hline
\end{tabular}

* According to Mann-Kendall test all the trends during this period are statistically significant $(p<=5 \%)$.

** Non-homogenised data

Zagreb shows similar tendencies of air temperature changes to Ljubljana, only the trends are less explicit (Table 3). In Zagreb, too, it was winters that have warmed most in the past 150 years. They have been by $1.8^{\circ} \mathrm{C}$ warmer in recent years than in the $1860 \mathrm{~s}$. They are followed by springs. Mean annual temperatures in recent years have been by a gross degree higher than at the beginning of the measurements. The trend of increasing of the mean annual temperatures amounts to $0.9^{\circ} \mathrm{C} / 100$ years, and is comparable to the warming trend in most of Europe which amounts to about $0.8^{\circ} \mathrm{C} / 100$ years (Beniston et al., 1998), and is slightly higher than the global warming trend $\left(0.74 \pm 0.18^{\circ} \mathrm{C}\right)$ (KajfežBogataj, 2008). In Zagreb, too, most of the warmest years have occurred in the last 15 years, whereas the coolest years were in the 19th century, with the exception of 1940.

Table 3: Variability of the air temperature in Zagreb in the period 1862-2010 (in ${ }^{\circ} \mathrm{C}$ ) Preglednica 3: Spremenljivost temperature zraka v Zagrebu v obdobju 1862-2010 $\left({ }^{\circ} \mathrm{C}\right)$

\begin{tabular}{|l|l|l|l|l|l|l|l|}
\cline { 2 - 8 } \multicolumn{1}{c|}{} & Avrg. & $\begin{array}{l}\text { Stand. } \\
\text { deviation }\end{array}$ & $\begin{array}{l}\text { Coolest sea- } \\
\text { son (year) }\end{array}$ & $\begin{array}{l}\text { Warmest } \\
\text { season (year) }\end{array}$ & $\begin{array}{l}\text { Trend* }\left({ }^{\circ} \mathrm{C} /\right. \\
100 \text { years })\end{array}$ & $\begin{array}{l}\text { The warmest } \\
\text { seasons (years) }\end{array}$ & $\begin{array}{l}\text { The coolest } \\
\text { seasons (years) }\end{array}$ \\
\hline Spring & 11.8 & 1.1 & $\begin{array}{l}9.4(1932, \\
1955)\end{array}$ & $15.0(2007)$ & $\begin{array}{l}+0.8 \\
(+0.9)^{* *}\end{array}$ & $\begin{array}{l}2007,2009,2000, \\
1920,1934\end{array}$ & $\begin{array}{l}1932,1955,1875, \\
1883\end{array}$ \\
\hline Summer & 21.1 & 0.9 & $19.0(1926)$ & $24.6(2003)$ & $\begin{array}{l}+0.7 \\
(+0.5)^{* *}\end{array}$ & $\begin{array}{l}2003,1992,1950, \\
1994\end{array}$ & $\begin{array}{l}1926,1913,1919, \\
1940\end{array}$ \\
\hline Autumn & 11.8 & 1.1 & $8.3(1912)$ & $14.5(1926)$ & $\begin{array}{l}+0.7 \\
(+0.6)^{* *}\end{array}$ & $\begin{array}{l}1926,2006, \\
2000,1963\end{array}$ & $\begin{array}{l}1912,1908,1915, \\
1921,1941\end{array}$ \\
\hline Winter & 1.5 & 2.0 & $\begin{array}{l}-4.4 \\
(1879 / 80)\end{array}$ & $6.9(2006 / 07)$ & $\begin{array}{l}+1.3 \\
(+1.5)^{* *}\end{array}$ & $\begin{array}{l}2006 / 07,2000 / 01, \\
1997 / 98,2008 / 09\end{array}$ & $\begin{array}{l}1879 / 80,1890 / 91, \\
1928 / 29,1939 / 40\end{array}$ \\
\hline Year & 11.5 & 0.8 & $9.5(1940)$ & $13.8(2000)$ & $\begin{array}{l}+0.9 \\
(+0.9)^{* *}\end{array}$ & $\begin{array}{l}2000,2007,1994, \\
2008,2009,2002\end{array}$ & $\begin{array}{l}1940,1864,1871, \\
1933\end{array}$ \\
\hline
\end{tabular}

* According to Mann-Kendall test all the trends during this period are statistically significant $(p<=5 \%)$.

** Non-homogenised data 


\subsection{Assessment of the impact of urban heat island on warming trends in Ljubljana}

The explicit trend of warming in Ljubljana - particularly in the last 30 years - that greatly exceeds the world average (Dolinar, Vertačnik, 2010) is the result of several factors. All the circumstances of measurements in individual periods, especially in the initial decades when air temperature was measured at non-standard times, are not known. However, the spreading of the city in the second half of the 20th century was certainly the main reason, since it was not possible to eliminate the impact of this factor with data homogenisation (Bertalanič et al., 2010). After the relocation of the meteorological station to the margin of the city in 1947, the surrounding areas of the measurement location were densely builtup and thus transformed from suburban to completely urban environment, which resulted in the urban heat island's impact on the measurements of temperatures. According to the researches performed by Jernej (2000), Ljubljana has a single-cell and stable urban heat island, where the city centre is warmer than its surroundings by about $1{ }^{\circ} \mathrm{C}$ in the annual average, by 1.2 to $1.5^{\circ} \mathrm{C}$ in summer months, and by 0.4 to $0.5^{\circ} \mathrm{C}$ in winter. Differences between the highest temperatures in the centre and the lowest ones in the southern, marshy outskirts of Ljubljana are from 5 to $7^{\circ} \mathrm{C}$, while in clear winter nights and the subsequent occurence of fog, when snow cover still lies outside the city, they can even reach $10^{\circ} \mathrm{C}$.

The impact of the urban heat island of Ljubljana on temperature trends can be assessed by comparing trends in Ljubljana and Zagreb before and after 1950, when the building-up of the surroundings of the Ljubljana meteorological station has started (Table 4). Between 1862 and 1950, both Zagreb and Ljubljana recorded a gradual increase in air temperatures, in terms of mean annual, winter, autumn and spring temperatures. Only the summer temperatures show no trend. Temperature rise was slightly more pronounced in Ljubljana, but the difference in trends, except the winter, was not greater than $0.2^{\circ} \mathrm{C}$. According to MannKendall test, none of the trends is statistically significant for Zagreb for this period, while the trends for winter and annual average air temperatures are statistically significant for Ljubljana. The summer temperatures started to increase intensively after 1950, particularly in Ljubljana, with linear trends ranging between $+1.0{ }^{\circ} \mathrm{C}$ (autumn) to $+2.1^{\circ} \mathrm{C}$ (summer) / 50 years. In Zagreb, trends are significantly lower, except for the winter. According to the Mann-Kendall test there in no statistically significant autumn temperature trend in Zagreb.

Similar winter air temperature rising trends are found for Zagreb and Ljubljana for the period after 1950. The warming trends for spring, summer and autumn are between 0.4 and $0.7{ }^{\circ} \mathrm{C} / 50$ years, and the mean annual temperature trend for $0.4{ }^{\circ} \mathrm{C} / 50$ years higher in Ljubljana than in Zagreb. When the trends are calculated on non-homogenised data which contain more non-climatic influences, they are higher for an additional one or two tenths of ${ }^{\circ} \mathrm{C}$ (Table 4). The biggest differences are found between the summer trends, which is not surprising. According to the findings of Jernej (2000), Ljubljana heat island's intensity is the highest in summer. The urban heat islands are the most intense in summer also in other cities of similar size and structure as Ljubljana, for example in Brno and Olomouc, Czech Republic (Dobrovolný et al., 2012; Vysoudil et al., 2012) and in other cities of Central Europe (Pongracz, Bartholy, Dezso, 2010). The gap between the warming trends in Ljubljana 
and Zagreb after 1950 may, in our opinion, be mainly explained by the impact of urban heat island, resulting from the urban growth of Ljubljana and the increased concentration of the built-up areas in the surroundings of the meteorological station. If we take these findings into account, we get 100-years warming trends for Ljubljana, which are slightly higher than the warming trends in most of Europe, but more comparable with them.

Table 4: Comparison of linear trends of air temperatures in Ljubljana and Zagreb in the periods 1862-1950 and 1951-2010

Preglednica 4: Primerjava linearnih trendov temperature zraka v Ljubljani in Zagrebu v obdobjih 1862-1950 in 1951-2010

\begin{tabular}{|c|c|c|c|c|c|c|c|c|}
\hline & \multicolumn{2}{|c|}{\begin{tabular}{|l|}
$1862-1950$ \\
$\left({ }^{\circ} \mathrm{C} / 100\right.$ years $)$ \\
Homogenised data
\end{tabular}} & \multicolumn{2}{|c|}{$\begin{array}{l}1862-1950 \\
\left({ }^{\circ} \mathrm{C} / 100 \text { years }\right) \\
\text { Non-homogenised data }\end{array}$} & \multicolumn{2}{|c|}{\begin{tabular}{|l|}
$1951-2010$ \\
$\left({ }^{\circ} \mathrm{C} / 50\right.$ years $)$ \\
Homogenised data
\end{tabular}} & \multicolumn{2}{|c|}{\begin{tabular}{|l|}
$1951-2010$ \\
$\left({ }^{\circ} \mathrm{C} / 50\right.$ years $)$ \\
Non-homogenised data
\end{tabular}} \\
\hline & Ljubljana & Zagreb & Ljubljana & Zagreb & Ljubljana & Zagreb & Ljubljana & Zagreb \\
\hline Spring & $+0.5^{*}$ & +0.3 & $+0.8^{*}$ & +0.7 & $+2.0 *$ & $+1.7 *$ & $+2.1^{*}$ & $+1.7^{*}$ \\
\hline Summer & +0.0 & +0.0 & +0.4 & +0.3 & $+2.1 *$ & $+1.4^{*}$ & $+2.2^{*}$ & $+1.5^{*}$ \\
\hline Autumn & +0.6 & +0.4 & +0.6 & +0.8 & $+1.0^{*}$ & +0.5 & $+1.2^{*}$ & +0.5 \\
\hline Winter & +0.9 & +0.4 & +1.4 & +1.3 & $+2.0^{*}$ & $+2.0 *$ & $+1.7^{*}$ & $+1.6^{*}$ \\
\hline Year & $+0.4 *$ & +0.2 & $+0.8^{*}$ & $+0.8^{*}$ & $+1.7^{*}$ & $+1.3^{*}$ & $+1.8^{*}$ & $+1.3^{*}$ \\
\hline
\end{tabular}

* Statistically significant trends, Mann-Kendall test $(p<=5 \%)$

Figure 5: Linear trends of mean annual air temperatures in Ljubljana and Zagreb in the periods 1862-1950 and 1951-2010

Slika 5: Linearni trendi povprečnih letnih temperatur zraka v Ljubljani in Zagrebu v obdobjih 1862-1950 in 1951-2010

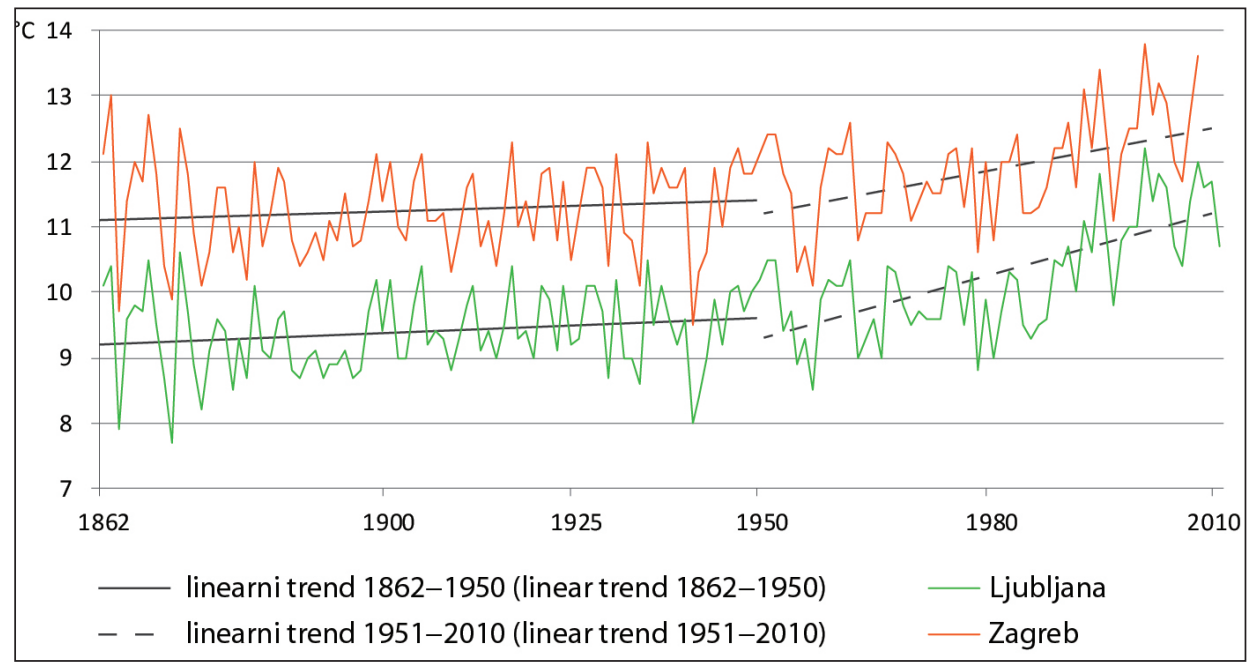




\section{CONCLUSION}

Comparison of long-term air temperature trends between Ljubljana and Zagreb demonstrated that the warming trends are more pronounced in Ljubljana. The trend for mean annual temperature in Ljubljana, calculated on the homogenised data, shows an increase by $+1.1^{\circ} \mathrm{C} / 100$ years while in Zagreb by $+0.9^{\circ} \mathrm{C} / 100$ years. The warming trend in Zagreb is comparable with trends in large parts of Europe, while the trends in Ljubljana exceed them. In both cities the most intensive warming has been found out in winter season, while the lowest trends are characteristic for summer and autumn air temperatures (Table 4).

The differences in the warming trends are even bigger when comparing trends since 1950. The trend of mean annual temperatures in Ljubljana amounts to $+1.7^{\circ} \mathrm{C} / 50$ years compared to $1.3{ }^{\circ} \mathrm{C} / 50$ years in Zagreb. Slightly higher $\left(+0.5^{\circ} \mathrm{C} / 50\right.$ years $)$ is the difference between the trends when calculated on non-homogenised data, containing effects of several non-climatic influences on temperature trends. The trend for Ljubljana in the last 30 years exceeds the world average (Dolinar, Vertačnik, 2010). The main reason is the expansion of the city in the second half of the 20th century, and the process of building-up the area surrounding the meteorological station in Ljubljana. This changed its character from suburban to urban, and resulted in a strong influence of urban heat island, whose impacts could not be eliminated with the data homogenisation (Bertalanič et al., 2010). By comparing trends for the two cities before and after 1950, the contribution of the urban heat island in Ljubljana to the warming trends after 1950 is estimated to be 0.3 to $0.4{ }^{\circ} \mathrm{C} /$ 50 years (even $0.5^{\circ} \mathrm{C} / 50$ years when calculated on non-homogenised data), and around $0.2^{\circ} \mathrm{C} / 100$ years on the long-term trends.

\section{(Translated by Marko Krevs)}

\section{Acknowledgements}

The study was carried out within the scope of the project The adaptation patterns of human activities to the environmental changes after Last Glacial Maximum in Slovenia (Vzorci prilagajanja človekovih dejavnosti spremembam v okolju po zadnjem glacialnem maksimumu v Sloveniji; J6-4016), funded by the Slovenian Research Agency (Javna agencija za raziskovalno dejavnost Republike Slovenije). Our thanks also go to D. Mlinek for his valuable help in collecting meteorological data and Dr. A. Filipčić for providing references on the climate of Zagreb.

\section{References}

Arhiv Urada za meteorologijo ARSO. Povprečne mesečne in letne temperature zraka za obdobje 1991-2011. URL: http://meteo.arso.gov.si/met/sl/archive/ (Cited June 2013). Auer, E., Böhm, R., Jurkovic, A., Lipa,W., Orlik, A., Potzmann, R., Schöner, W., Ungersböck, M., Matulla, C., Briffa, K., Jones, P., Efthymidis, D., Brunetti, M., Nanni, T., Maugeri, M., Mercalli, L., Mestre, O., Moisselin, J.-M., Begert, M., Müller-Westermeier, G., Kveton, V., Bochnicek, O., Stastny, P., Lapin, M., Szalai, S., Szentimrey, T., Cegnar, T., Dolinar, 
M., Gajic-Capka, M., Zaninovic, K., Majstorovic, Z., Nieplova, E., 2007. HISTALP-historical instrumental climatological surface time series of the Greater Alpine Region. International journal of climatology, 27, 1, p. 17-46. DOI: 10.1002/joc.1377

Beniston, M., Tol, R. S. J., Delecolle, R., Hoerman, G., Iglesias, A., Innes, J., McMichael, A. J., Martens, W. J. M., Nemesova, I., Nicholls, R., Toth, F. L., Kovats, S., Leemans, R., Stojic, Z., 1998. Regional impacts of climatic change on Europe. Special report of the Intergovernmental Panel on Climate Change (IPCC), Chapter 5. Cambridge, Cambridge University Press, p. 149-185. URL: http://www.ipcc.ch/ipccreports/sres/ regional/index.php?idp=91 (Cited 14. 3. 2015).

Bertalanič, R., Demšar, M., Dolinar, M., Dvoršek, D., Nadbath, M., Pavčič, B., Roethel-Kovač, M., Vertačnik, G., Vičar, Z., 2010. Spremenljivost podnebja v Sloveniji. Ljubljana, ARSO, 11 pp.

Bokwa, A., 2011. The urban heat island in Kraków, Poland. Moravian geographical report, 19, 3, p. 2-7. URL: http://www.geonika.cz/EN/research/ENMgr/MGR_2011_03.pdf (Cited 1. 12. 2015).

Bottyán, Z., Kircsi, A., Szegedi, S., Unger, J., 2005. The relationship between built-up areas and the spatial development of the mean maximum urban heat island in Debrecen, Hungary. International journal of climatology, 25, 3, p. 405-418. DOI: 10.1002/joc.1138

Dobrovolný, P., Řezníčková, L., Brázdil, R., Krahula, L., Zahradníček, P., Hradil, M., Doleželová, M., Šálek, M., Štěpánek, P., Rožnovský, J., Valášek, H., Kirchner, K., Kolejka, J., 2012. Klima Brna. Víceúrovňová analýza městského klimatu. Brno, Masarykova univerzita, $200 \mathrm{pp}$.

Dolinar, M., Nadbath, M., Vičar, Z., Vertačnik, G., Pavčič, B., 2010. Spremljanje podnebja v Sloveniji. In: Cegnar, T. (Ed.). Okolje se spreminja. Podnebna spremenljivost Slovenije in njen vpliv na vodno okolje. Ljubljana, ARSO, p. 17-35. URL: http:// www.arso.gov.si/o\%20agenciji/knji\%C5\%BEnica/publikacije/Okolje_se\%20spreminja.pdf (Cited 14. 3. 2015).

Dolinar, M., Vertačnik, G., 2010. Spremenljivost temperaturnih in padavinskih razmer v Sloveniji. In: Cegnar, T. (Ed.). Okolje se spreminja. Podnebna spremenljivost Slovenije in njen vpliv na vodno okolje. Ljubljana, ARSO, p. 37-40. URL: http://www. arso.gov.si/o\%20agenciji/knji\%C5\%BEnica/publikacije/Okolje_se\%20spreminja. pdf (Cited 14. 3. 2015).

Gams, I., Krevs, M., 1990. Ali nam grozi poslabšanje podnebja? Ujma, 4, p. 147-154.

Gartland, L., 2008. Heat islands: understanding and mitigating heat in urban areas. London, Earthscan, 208 pp.

Gavazzi, A., 1925. O meteoroloških postajah v Sloveniji. Geografski vestnik, 1, p. 55-61. Goldberg, J.,1953. Prilozi istraživanju klimatskih fluktuacija u Jugoslaviji. Radovi Geofizičkog instituta u Zagrebu, 3, 27 pp.

Herak, D., Penzar, B., Herak, M., 2011. Ljetopis Geofizičkog zavoda. In: Orlić, M. (Ed.). Nulla dies sine observatione: 150 godina Geofizičkog zavoda u Zagrebu. Zagreb, Geofizički odsjek Prirodoslovno-matematičkog fakulteta Sveučilišta u Zagrebu, p. 9-32. URL: https://www.pmf.unizg.hr/images/site_1701/150_Geofizicki_zavod.pdf (Cited 25. 5. 2015). 
Hirsch, R. M., Slack, J. R., Smith, R. A., 1982. Techniques of trend analysis for monthly water quality data. Water resources research, 18, 1, p. 107-121. DOI: 10.1029/ WR018i001p00107

HISTALP, historical instrumental climatological surface time series of the Greater Alpine Region. URL: http://www.zamg.ac.at/histalp/dataset/station/csv.php (Cited 15. 2. 2015).

Jernej, S., 2000. Mestna klima. In: Gabrovec, M., Orožen Adamič, M. (Eds.). Ljubljana: geografija mesta. Ljubljana, Založba ZRC, p. 117-130.

Juras, J., 1985. Neke karakteristike promjene klime Zagreba u poslednjem tridesetljeću. Geofizika, 2, p. 93-102. URL: http://geofizika-journal.gfz.hr/Vol_02/02-07-juras.pdf (Cited 25. 5. 2015).

Kajfež-Bogataj, L., 1990. Analiza zimskih temperatur zraka v Ljubljani. Zbornik Biotehniške fakultete UL, 55, p. 7-14.

Kajfež-Bogataj, L., 1992. Vpliv pričakovanih klimatskih sprememb na živi svet. Geografija v šoli, 2, p. 47-55.

Kajfež-Bogataj, L., 2008. Kaj nam prinašajo podnebne spremembe? Ljubljana, Pedagoški inštitut, $134 \mathrm{pp}$.

Katušin, Z., 2011. Sustavna mreža meteoroloških postaja na području Hrvatske od prvih početaka 1851 do 2011 (Kretanje broja meteoroloških postaja u odnosu na povjesne i organizacijske promjene). Državni hidrometeorološki zavod R Hrvatske, Prikazi, 22, 22 pp. URL: http://klima.hr/razno/publikacije/prikazi22.pdf(Cited 25. 5. 2015).

Kendall, M. G., 1975. Rank correlation methods. 4th edition. London, Charles Griffin, $272 \mathrm{pp}$.

Kim, Y.-H., Baik, J.-J., 2002. Maximum urban heat island intensity in Seoul. Journal of applied meteorology, 41, p. 651-659. URL: http://journals.ametsoc.org/doi/ pdf/10.1175/1520-0450\%282002\%29041\%3C0651\%3AMUHIII\%3E2.0.CO\%3B2 (Cited 30. 11. 2015).

Klimatografija Slovenije. Temperatura zraka 1961-1990. 1995. Ljubljana, Hidrometeorološki zavod Republike Slovenije, 356 pp.

Konovšek, A., 2006. Mezoklimatske razmere Šaleške doline in mestna klima Velenja. In: Šalej, M. (Ed.). Šaleška in Zgornja Savinjska dolina. Zbornik 19. zborovanja slovenskih geografov, Velenje, ERICO, Inštitut za ekološke raziskave, str. 76-86.

Krevs, M., 1986. Spremenljivost klime v Ljubljani in Trstu v obdobju 1851-1985. Seminarska naloga. Ljubljana, Filozofska fakulteta, Oddelek za geografijo, 155 pp.

Lazar, R., Buchroithner, M. F., Kaufmann, V., 1995. Stadtklimaanalyse Graz. Graz, Magistrat Graz, $161 \mathrm{pp}$.

Mann, H. B., 1945. Non-parametric test of randomness against trend. Econometrica, 13, 3, p. 245-259. DOI: $10.2307 / 1907187$

Manohin, V., 1952. Kratek pregled temperatur in padavin v Ljubljani v 100-letni opazovalni dobi 1851-1950. Geografski vestnik, 24, p. 135-144.

Manohin, V., 1965. Nekatere značilnosti zimskih temperatur v Ljubljani v zadnjih 115 letih. Razprave-Papers, Društvo meteorologov Slovenije, 6, p. 5-18. 
Meteorological and Hydrological Service of Republic of Croatia. Monthly and yearly average air temperatures for meteorological station Zagreb-Grič from 1990-2010. Zagreb (Obtained in October 2012).

Mohorovičić, A., 1897. Klima grada Zagreba. Rad JAZU, 131, p. 72-111.

Montávez, J. P., Rodrígues, A., Jiménez, J. I., 2000. A study of the urban heat island of Granada. International journal of climatology, 20, 8, p. 899-911. DOI: 10.1002/1097-0088(20000630)20:8<899::AID-JOC433>3.0.CO;2-I

Ogrin, D., 1996. Podnebni tipi v Sloveniji. Geografski vestnik, 68, p. 39-56.

Ogrin, D., 2003. Spreminjanje temperature zraka in padavin po letnih časih v Ljubljani in Trstu v obdobju 1851-2002. Dela, 20, p. 115-131.

Ogrin, D., 2015. Long-term air temperature changes in Ljubljana (Slovenia) in comparison to Trieste (Italy) and Zagreb (Croatia). Moravian geographical reports, 23, 3, p. 17-26. DOI: 10.1515/mgr-2015-0014

Ogrin, D., Plut, D., 2009. Aplikativna fizična geografija Slovenije. Ljubljana, Znanstvena založba Filozofske fakultete, 246 pp.

Oke, T. R., 1999. Boundary layer climates (2nd edition). London, Routledge, 435 pp.

Penzar, I., Juras, J., Marki, A., 1992. Long-term meteorological measurements at Zagreb: 1862-1990. Geofizika, 9, Suppl., 171 pp. URL: http://geofizika-journal.gfz.hr/ Vol_09_Supplement/09Suppl_01_penzar_et_al.pdf (Cited 25. 5. 2015).

Penzar, B., Penzar, I., Juras, J., Marki, A., 1992a. Brief review of climatic fluctuations recorded in Zagreb between 1862 and 1990. Geofizika, 9, 1, p. 57-67. URL: http:// hrcak.srce.hr/index.php?show=clanak\&id_clanak_jezik=31532 (Cited 25. 5. 2015).

Pongracz, R., Bartholy, J., Dezso, Zs., 2010. Application of remotely sensed thermal information to urban climatology of Central European cities. Physics and chemistry of the Earth, Parts A/B/C: Bio-, agro-, and urban climatology, 35, 1-2, p. 95-99. DOI: 10.1016/j.pce.2010.03.004

Povše, M., 1984. Imenik ali seznam krajev z vremenskimi postajami v SR Sloveniji in kronološkim pregledom dosedanjih meteoroloških opazovanj. Elaborat, HMZ Slovenije, Ljubljana, 107 pp.

Radić, V., Pasarić, N., Šinik, N., 2004. Analiza zagrebačkih klimatoloških nizova pomoću empirijski određenih prirodnih sastavnih funkcija. Geofizika, 21, 1, p. 15-36. URL: http://hrcak.srce.hr/17006 (Cited 25. 5. 2015).

Souch, K., Grimmond, S., 2006. Applied climatology: urban climate. Progress in physical geography, 30, 2, p. 270-279. DOI: 10.1191/0309133306pp484pr

Šegota, T., 1970. Sekularne fluktuacije temperature u Zagrebu. Geografski glasnik, 32, p. 39-60.

Šegota, T., 1981. More about the secular fluctuations of air temperature in Zagreb, Croatia. Quaestiones Geographicae, 7, p. 147-154.

Trontelj, M., 2000. 150 let meteorologije na Slovenskem: ob 150-letnici meteorološke postaje v Ljubljani. Ljubljana, Hidrometeorološki zavod RS, 52 pp.

Vysoudil, M., Jurek, M., 2005. Summer air temperatures in Ljubljana (Slovenia) and Olomouc (Czech Republic) in the period 1961-2000. Dela, 23, p. 245-257. URL: http://revije.ff.uni-lj.si/Dela/article/view/dela.23.7.245-257/1304 (Cited 25. 5. 2015). 
Vysoudil, M., Frajer, J., Geletič, J., Lehnert, M., Lipina, P., Pavelková Chmelová, R., Repka, M., 2012. Podnebí Olomouce. Univerzita Palackého v Olomouci, Olomouc, 211 pp. Wanner, H., 1991. Studie Biel - Klima und Luftverschmutzung einer Schweizer Mittelstadt. Bern, Haupt Verlag, 455 pp.

Zaninović, K., 2006. Trends in indices of temperature extremes in Croatia, 1901-2004. Sixth European conference on applied climatology (ECAC), Ljubljana, Slovenia, 4-8 September 2006. CD (Abstracts, A-00470).

Žiberna, I., 1991. Nekatere značilnosti mestne klime Maribora. Dela, 8, p. 72-84. URL: http://revije.ff.uni-lj.si/Dela/article/view/1187/992 (Cited 30. 11. 2015).

\section{OCENA VPLIVA MESTNEGA TOPLOTNEGA OTOKA NA DOLGO- ROČNE TRENDE SEGREVANJA OZRAČJAV LJUBLJANI}

\section{Povzetek}

V prispevku je ocenjen vpliv mestnega toplotnega otoka Ljubljane na trend segrevanja ozračja. Ocena temelji na primerjavi dolgoročnih trendov temperature zraka v Ljubljani in Zagrebu. Meteorološka postaja Zagreb-Grič deluje od ustanovitve leta 1862 ves čas na griču v središču mesta, medtem ko se je ljubljanska postaja večkrat selila. $Z$ vidika homogenosti podatkov in trenda segrevanja je pomembna selitev po 2. svetovni vojni iz centra Ljubljane na mestno obrobje za Bežigrad, ki je bil v naslednjih desetletjih urbaniziran. S tem so postopoma prišle meritve temperature zraka pod močan vpliv mestnega toplotnega otoka, ki ga pri homogenizaciji podatkov ni mogoče v celoti odpraviti.

Povprečne letne temperature zraka, izračunane na podlagi homogeniziranih podatkov, imajo v Ljubljani in Zagrebu enako spremenljivost, nekaj razlik je v spremenljivosti sezonskih temperatur. V obeh mestih so najbolj spremenljive zimske temperature, najmanj pa poletne. Zime se med vsemi letnimi časi od sredine 19. st. do danes tudi najbolj izrazito segrevajo.

Zaradi bolj celinskega značaja temperaturnega režima bi pričakovali, da so trendi segrevanja ozračja višji v Zagrebu kot v Ljubljani. Vendar izračuni kažejo, da so trendi segrevanja ozračja v Ljubljani, izračunani iz homogeniziranih in nehomogeniziranih podatkov (Preglednici 2 in 3), izrazitejši. Sezonske temperature se v Ljubljani brez izjeme od sredine 19. st. do današnjih dni dvigujejo. Trend ogrevanja je najbolj izrazit pozimi, saj so se zimske temperature v Ljubljani od srede 19. st. do današnjih dni zvišale za nekaj več kot $2{ }^{\circ} \mathrm{C}$. Do začetka 20 . st. so bile zime podpovprečno hladne, sredi prve polovice tega stoletja so se vrstile nadpovprečno tople zime, v naslednjih desetletjih so bile zimske temperature okoli 150-letnega povprečja. Od 80. let 20. st. dalje sledi izrazit trend naraščanja zimskih temperatur. Zimskemu trendu sledi trend dvigovanja pomladnih temperatur in trend povprečnih letnih temperatur. Poletne temperature zlasti izrazito naraščajo v zadnjih 25 letih, ko je povprečna poletna temperatura za 1,5 stopinje višja od 160-letnega povprečja.

Najhladnejše leto v obravnavanem obdobju je bilo 1871, najtoplejše pa leto 2000. Zelo topla leta si večinoma sledijo od leta 2000 dalje. Najhladnejše zime so bile v prvih 
sto letih meritev. Zelo tople zime so značilne predvsem za obdobje zadnjih 20 let (najtoplejša zima 2006/07), tople so bile zime tudi v začetku 20. st., ki jim je sledilo obdobje hitrega zniževanja zimskih temperatur. Najtoplejše poletje je bilo leta 2003. Razen v zadnjih dveh desetletjih je bilo nekaj nadpovprečno toplih poletij še na začetku meritev in sredi 20. st. Nasprotno so se hladna poletja v Ljubljani vrstila na začetku meritev in v prvi polovici 20 . st.

Zagreb ima podobne tendence spreminjanja temperature zraka kot Ljubljana, le da so trendi manj izraziti (Preglednica 3). Tudi v Zagrebu so se v zadnjih 150 letih najbolj segrele zime, ki so v zadnjih letih za $1,8{ }^{\circ} \mathrm{C}$ toplejše kot v 60 . letih 19 . st. Sledijo jim trendi pomladanskih temperatur. Povprečne letne temperature so v zadnjih letih za stopinjo višje kot so bile v začetku meritev. Trend segrevanja povprečnih letnih temperatur znaša v Zagrebu $+0,9{ }^{\circ} \mathrm{C} / 100$ let. Trend je na ravni stoletnih trendov v večjem delu Evrope (Beniston in sod., 1998) in je nekoliko višji kot je trend segrevanja našega planeta $(+0,74$ $\pm 0,18{ }^{\circ} \mathrm{C}$ ) (Kajfež-Bogataj, 2008). Tudi v Zagrebu se je večina najtoplejših let zvrstila v zadnjih 15 letih, medtem ko so bila najhladnejša, z izjemo leta 1940, v 19. st.

Izrazit trend segrevanja ozračja v Ljubljani, še posebej v zadnjih 30 letih, ki daleč presega svetovno povprečje (Dolinar, Vertačnik, 2010), je posledica več dejavnikov. Zaradi pestre zgodovine meteorološke postaje kljub izvedeni homogenizaciji ni mogoče povsem izključiti vpliva pogostih selitev merilnega mesta in načina meritev na rezultat. Vsi pogoji meritev v posameznih obdobjih, še posebej v začetnih desetletjih, ko so temperaturo zraka merili ob nestandardnih terminih, niso znani. Glavni razlog nadpovprečnega segrevanja ozračja v Ljubljani je prav gotovo širitev mesta v drugi polovici 20. st., saj pri homogenizaciji podatkov tega dejavnika ni bilo mogoče odpraviti (Bertalanič in sod., 2010). Po preselitvi meteorološke postaje leta 1947 na mestno obrobje so okolico merilnega mesta $\mathrm{V}$ naslednjih desetletjih gosto pozidali in jo iz primestne spremenili v povsem mestno, s čimer so meritve prišle pod močan vpliv mestnega toplotnega otoka. Po raziskavah Jerneja (2000) ima Ljubljana enoceličen in stabilen toplotni otok, kjer je mestno središče v letnem povprečju toplejše od okolice za okoli $1^{\circ} \mathrm{C}$, v poletnih mesecih 1,2 do $1,5{ }^{\circ} \mathrm{C}$, pozimi pa 0,4 do $0,5^{\circ} \mathrm{C}$. Razlike med najvišjimi temperaturami v središču in najnižjimi v južni, barjanski okolici Ljubljane, so 5 do $7^{\circ} \mathrm{C}$, ob jasnih zimskih nočeh in nekoliko poznejšem nastanku megle, ko je izven mesta še snežna odeja, pa lahko narastejo do $10^{\circ} \mathrm{C}$.

Kakšen je vpliv mestnega toplotnega otoka Ljubljane na temperaturne trende, lahko ocenimo s primerjavo trendov v Ljubljani in Zagrebu pred in po letu 1950, ko se je začela pozidava okolice ljubljanske meteorološke postaje (Preglednica 4). Med letoma 1862 in 1950 tako v Zagrebu kot Ljubljani beležimo postopno dviganje temperature zraka (le poletne temperature ne kažejo trenda spreminjanja). Segrevanje je bilo nekoliko izrazitejše v Ljubljani, vendar razen pozimi razlika v trendih ni bila večja od $0,2{ }^{\circ} \mathrm{C}$. Mann-Kendallov preizkus kaže, da za Zagreb v tem obdobju noben od trendov ni statistično značilen, za Ljubljano pa sta značilna trenda za zimo in povprečno letno temperaturo zraka. Po letu 1950 so začele temperature zraka skokovito naraščati, še posebej v Ljubljani. Linearni trendi zanjo se gibljejo med $+1{ }^{\circ} \mathrm{C}$ (jesen) do $+2,1{ }^{\circ} \mathrm{C}$ (poletje) / 50 let. V Zagrebu so trendi, razen za zimo, občutno nižji. Jesenski meseci po Mann-Kendallovem preizkusu ne kažejo statistično značilnega trenda. 
Razen zim, ki so se $\mathrm{v}$ Zagrebu in Ljubljani segrevale s podobnim trendom, so trendi segrevanja v Ljubljani po letu 1950 za letne čase višji med 0,4 in $0,7^{\circ} \mathrm{C} / 50$ let, za povprečne letne temperature $0,4^{\circ} \mathrm{C} / 50$ let. Še za desetinko do dveh desetink ${ }^{\circ} \mathrm{C} / 50$ let so razlike večje, če trende izračunamo iz nehomogeniziranih podatkov (Preglednica 4), ki vsebujejo več neklimatskega signala. Da je razlika med mestoma največja med poletnimi trendi, ni presenetljivo, saj je po ugotovitvah Jerneja (2000) intenziteta ljubljanskega toplotnega otoka tedaj največja. Poleti je mestni toplotni otok najbolj intenziven tudi v drugih mestih podobne velikosti in strukture kot Ljubljana, npr. v Brnu na Češkem (Dobrovolný in sod., 2012). Večino razkoraka v trendu segrevanja med Ljubljano in Zagrebom po letu 1950 lahko, po našem mnenju, pripišemo prav vplivu mestnega toplotnega otoka oziroma širjenju Ljubljane in zgoščanju pozidave okoli meteorološke postaje. 